Guariglia, A., Spaliara, M. E. and Tsoukas, S. (2016) To what extent does the interest burden affect firm survival? Evidence from a panel of UK firms during the recent financial crisis. Oxford Bulletin of Economics and Statistics, 78(4), pp. 576-594. (doi:10.1111/obes.12120)

There may be differences between this version and the published version. You are advised to consult the publisher's version if you wish to cite from it.

This is the peer-reviewed version of the following article: Guariglia, A., Spaliara, M. E. and Tsoukas, S. (2016) To what extent does the interest burden affect firm survival? Evidence from a panel of UK firms during the recent financial crisis. Oxford Bulletin of Economics and Statistics, 78(4), pp. 576-594, which has been published in final form at 10.1111/obes.12120. This article may be used for non-commercial purposes in accordance with Wiley Terms and Conditions for SelfArchiving.

http://eprints.gla.ac.uk/106887/

Deposited on: 19 July 2016

Enlighten - Research publications by members of the University of Glasgow http://eprints.gla.ac.uk 


\title{
To what Extent Does the Interest Burden Affect Firm Survival? Evidence from a Panel of UK Firms during the Recent Financial Crisis ${ }^{*}$
}

\author{
ALESSANDRA GUARIGLIA ${ }^{+}$, MARINA-ELIZA SPALIARA ${ }^{++}$, AND SERAFEIM \\ TSOUKAS $^{++}$
}

+ Department of Economics, University of Birmingham, Edgbaston, Birmingham, B15 2TT, UK. (e-mail: a.guariglia@bham.ac.uk)

${ }^{++},++$Department of Economics, Adam Smith Business School, Gilbert Scott Building, University of Glasgow, Glasgow, G12 8QQ, UK. (e-mail: serafeim.tsoukas@glasgow.ac.uk, marina.spaliara@glasgow.ac.uk)

\begin{abstract}
Using a panel of mainly unquoted UK firms over the period 2000-09, we document a significant effect of changes in the interest burden from debt-servicing on firm survival. The effect is found to be stronger during the recent financial crisis compared with more tranquil periods. Furthermore, the survival chances of bank-dependent, younger, and nonexporting firms are most affected by changes in the interest burden, especially during the crisis. Our results are robust to using different estimation methods and different interest burden measures. They suggest that one way for policymakers to mitigate the effects of financial crises by limiting firm failures would be to prevent financing costs from rising, especially for those firms more likely to face liquidity constraints.
\end{abstract}

(Word count: 8,746+ 3 tables $=10,246)$

\footnotetext{
${ }^{*}$ JEL Classification numbers: D21; E22; E32; G31.

We thank the Editor and two anonymous referees for very helpful comments and suggestions. We are also grateful to Markus Eberhardt, Richard Harris, Kishore Kamath, Stephen Millard, Daphne Nicolitsas, George Panos and Evan Wohlmann for useful comments, as well as to participants at seminars at the Bank of England, the Bank of Greece, the Universities of Glasgow, Leicester, Patras, and Stirling, and at the 2012 European Association for Research in Industrial Economics meetings, the 2013 European Meetings of the Econometric Society, and the 2013 Royal Economic Society conference. The first and second authors gratefully acknowledge financial support from the British Academy. Any remaining errors are our own.
} 


\section{Introduction}

In August 2007, an irregular pattern of financial difficulties became a fully-fledged financial crisis involving most of the world's largest banks (see Goodhart, 2008, for a survey). These events had a strong impact on UK financial markets in general and the banking sector in particular. Due to the turmoil in financial markets, at the end of the third quarter of 2008, 1.4 million small firms in the UK reported a severe shortage of credit, and some $30 \%$ of firms considered shutting down their operations altogether unless credit became cheaper and more easily available (Kirkup and Tyler, 2008) ${ }^{1}$. In addition, according to the Federation of Small Businesses, almost 30,000 small and medium-sized enterprises (SMEs) failed in 2009, while figures provided by the Office for National Statistics (2010) show that the corporate death rate in the UK at the end of 2009 was 11.8\%. Paying special attention to England and Wales during the early 1990s recession and the current financial crisis, Benito et al. (2010) confirm that company liquidations rise during recessionary periods. This evidence suggests the presence of a strong link between the shortage and high cost of credit, which typically characterizes recessions, and firm failures.

The purpose of this paper is to further investigate the effects of the recent financial crisis on firms' survival chances. To this end, we focus on the impact of changes in a firmspecific interest rate (which we call interest burden and define as the ratio of a firm's total interest payments to cash flow) on business failures in the UK over the period 2000-2009, and assess whether the strength of this impact increased during the crisis years.

Our study is motivated by the financial accelerator-related hypothesis according to which deteriorations in economic conditions increase the cost of finance, which in turn

\footnotetext{
${ }^{1}$ Similarly, according to the British Chambers of Commerce (BCC), one third of small and medium-sized businesses in the UK faced difficulties in accessing finance during the recent crisis. Even more recently, access to finance remains a "major barrier" to growth for more than one in five small companies, with $41 \%$ of loan applications refused in the three months to February 2012 (Kuchler, 2012).
} 
weakens firms' balance sheet positions, thus influencing their ability to borrow, and, consequently, their activities and survival chances (Bernanke et al., 1996; Perez-Quiros and Timmermann, 2000; Vermeulen, 2002). It is well accepted that firms' interest burden is inversely related to their balance sheet positions. A high interest burden can in fact be seen as evidence that the firm is charged a high external finance premium. The countercyclical movement in the premium for external funds amplifies borrowers' spending and economic activity through the financial accelerator (Bernanke et al., 1996). Thus, the debt servicing cost is expected to affect firms' real and financial decisions, as well as their survival prospects.

The present study makes two important contributions to the literature. First, while previous papers have included balance sheet variables in equations modeling firm survival (Bunn and Redwood, 2003; Bridges and Guariglia, 2008), the literature is silent on the role of the firm-specific interest burden in determining firms' chances of failure. Considering the evidence according to which higher levels of interest payments negatively affect fixed investment and employment decisions at the firm-level (Nickell and Nicolitsas, 1999; Benito, 2005; and Benito and Young, 2007), we move this literature forward by investigating, for the first time, the links between firms' interest burden and their survival chances. As firms' real activities are adversely affected by a rise in borrowing costs, we expect higher levels of the interest burden to be associated with lower chances of firm survival. Moreover, we differentiate the effects of changes in the interest burden on firm survival over a tranquil period (2000-2006) and the financial crisis period (2007-2009), focusing on the UK, which was particularly affected by the crisis (Rose and Spiegel, 2011). This may help us understand the channels through which the financial crisis led to the failure of several UK firms, and in particular several small and medium-sized enterprises (SMEs). 
Our second contribution is that contrary to most of the literature, which looked at the effects of the financial crisis focusing on listed companies (e.g. Kahle and Stultz, 2013; Santos, 2013), we focus on a large panel of mainly unlisted firms. As unlisted companies are typically younger and smaller than their listed counterparts, they are more likely to face problems of asymmetric information, and are hence more likely to be affected by liquidity constraints (Hughes, 1994). Focusing on unlisted companies allows us therefore to provide a sharper analysis of the effects of the recent financial crisis on corporate behavior than previously done in the literature.

In addition, the size of our panel enables us to take into account three dimensions of firm heterogeneity (bank dependency, age, and export status), aimed at measuring the degree of financing constraints faced by firms. This is an important contribution in the light of the fact that the firms in our sample are heterogeneous and unlikely to be affected by changes in the interest burden in the same way. Our first dimension of firm heterogeneity is based on the extent to which firms can be considered as bank-dependent. It is now well documented that since the onset of the crisis, banks have incurred severe losses, which have led them to significantly increase the cost of loans directed towards bank-dependent firms (Santos, 2013). Also considering that the pool of funds that banks could lend was reduced during the crisis (Ivashina and Scharfstein, 2010), this suggests that bank-dependent firms are likely to have suffered more from the effects of the crisis than their less bank-dependent counterparts. Next, we differentiate old from young firms, whereby the latter are likely to face a higher degree of information asymmetries due to the lack of track record reputation, and hence a higher degree of financing constraints (Hadlock and Pierce, 2010). Finally, we distinguish exporters from non-exporters, whereby the former are less likely to face financing constraints (Greenaway et al., 2007). We expect 
bank-dependent, younger, and non-exporting firms' failure probabilities to be most affected by changes in the interest burden, especially during the crisis years.

We find that the interest burden has a significant effect on firm survival, and that this effect is stronger during the recent financial crisis compared with more tranquil periods. Furthermore, the survival chances of bank-dependent, younger, and non-exporting firms are most affected by changes in the interest burden, especially during the crisis. Our results are robust to using different estimation methods and different interest burden measures.

The remainder of the paper is organized as follows. Section II provides some economic background for our research. In section III, we illustrate our empirical specifications and the main hypotheses that we test. Section IV describes our data and presents some summary statistics. Section V illustrates our main empirical results. Section VI provides some robustness tests, and Section VII concludes and discusses some policy implications.

\section{Economic background}

In a world characterized by asymmetric information between borrowers and lenders, there exists a wedge between the cost of funds generated externally (by issuing debt or equity) and internally (by retained earnings, Bernanke and Gertler, 1995; Bernanke et al., 1996). As general interest rates (and hence the interest burden) rise, firms’ net worth is reduced ${ }^{2}$, and their balance sheet situation worsens. Due to moral hazard and adverse selection problems, this reduces lending to firms through the balance sheet channel (Bernanke and Gertler, 1995). This happens because banks reduce their actual lending to firms and/or because they charge rates so high that the borrowers can no longer afford to take up the

\footnotetext{
${ }^{2}$ Net worth comprises the firm's liquid assets and marketable securities. This includes cash flow. A rise in interest rates lowers cash flow, which, in turn, leads to a lower net worth.
} 
loans. The upshot is that due to this reduced access to external finance, firms' investment and other corporate activities decline, which in the extreme, may lead to a rising probability of bankruptcy (Nickell and Nicolitsas, 1999). Small and young firms, and more in general, firms more likely to suffer from asymmetric information problems and financing constraints, will be most affected by this channel, as banks are always more reluctant to lend to them, and because they typically suffer from a higher wedge between the cost of external and internal funds.

This problem is likely to be exacerbated during periods of recession, which are characterized by sustained increases in the cost of external finance, independent on any monetary policy shift, through the financial accelerator (Bernanke et al., 1996). As the quality of borrowers deteriorates, which is typical during recessionary periods, lenders require in fact a higher spread to compensate them for the increased risk of lending (Santos and Winton, 2008). Being typically more risky, financially constrained firms are most likely to be charged even higher interest rates. This negatively affects their net worth, and provokes, in turn, a further reduction in their ability to borrow, further reducing their spending, investment, and production, raising their probability of bankruptcy, and magnifying the effects of the recession. Perez-Quiros and Timmermann (2000) propose a similar argument and further claim that because small firms, which are typically considered as financially constrained, are likely to be bank-dependent, they are also likely to be affected by the fact that under tighter credit conditions, the pool of funds that banks can lend out is reduced.

The international evidence on the recent financial crisis is indicative of a rise in the cost of credit and of a drop in firms' access to external finance. For instance, recent evidence shows that banks, and especially those which incurred the largest losses in connection with the subprime meltdown, monitored their borrowers more closely, 
increased the cost of loans directed towards firms, and, more in general, became more cautious in their lending practices (Santos, 2013). Bank-dependent borrowers suffered more from this problem than borrowers with access to bond markets (Santos, 2013). Along similar lines, Ivashina and Scharfstein (2010) document a strong reduction in the supply of bank credit during the financial crisis, and Almeida et al. (2013) also note a significant drop in firms' access to external financing during the crisis, and claim this was a major determinant of firms' survival.

Focusing on the UK, the Bank of England reports a reduction of loans to private non-financial corporations (PNFCs) from UK monetary financial institutions during the financial crisis. Specifically, loans to PNFCs fell by £3.6 bn from 2007 to 2008, and by another $£ 3.9$ bn in $2009^{3}$. In addition, Bell and Young (2010) argue that the cost of credit rose sharply during the financial crisis, especially for SMEs. Yet, to the best of our knowledge, the extent to which this increase in the cost of credit has affected firms' survival chances in the UK context has not been investigated. Our paper fills this gap in the literature.

\section{Empirical implementation}

\section{Baseline specification}

In order to establish the extent to which financial pressure from debt-servicing costs affects firms' survival prospects, we model the determinants of firm survival and check whether the interest burden significantly affects it. In line with Bunn and Redwood (2003), Bridges and Guariglia (2008), and Helmers and Rogers (2010, 2011), we define a firm as failed in a given year when its status is that of receivership, liquidation, or dissolved.

\footnotetext{
${ }^{3}$ See the Bank of England Statistical Interactive Database (www.bankofengland.co.uk/mfsd/iadb).
} 
Following recent literature on firm survival (Bandick and Görg and, 2010; Tsoukas, 2011; and Görg and Spaliara, 2014), our empirical models are estimated using the complementary log-log (cloglog) model, which is equivalent to the discrete time version of the Cox proportional hazard model ${ }^{4}$. The baseline proportional hazard is formulated as:

$$
h(j, X)=1-\exp \left[-\exp \left(\beta^{\prime} X+\gamma_{j}\right)\right]
$$

where $h(j, X)$ is the interval hazard for the period between the beginning and the end of the $j^{\text {th }}$ year after the first appearance of the firm. The $\beta$ parameters show the effects of the explanatory variables $X$ on the hazard rate, and $\gamma$ captures period-specific effects on the hazard. To test whether firm exit is affected by the firm-specific interest rate, we include the interest burden (IB) among the explanatory variables.

The effects of changes in firm-specific interest payments on various aspects of firm behavior have been analyzed in previous literature. For instance, focusing on the UK, Nickell and Nicolitsas (1999) find that, controlling for expected wages and demand, an increase in the borrowing ratio (which they define as the ratio of interest payments to cash flow) has a large negative effect on firm-level employment. Benito (2005) shows that the same borrowing ratio is negatively related to firm-level inventory investment in both the UK and Spain; and Benito and Young (2007), that it also affects fixed investment, new equity issues, and dividend payments. Mojon et al. (2002) show that the mean interest on financial debt paid by small firms in the Euro area is on average higher than that paid by larger firms, and strongly affects firms' fixed investment. Benito and Whitley (2003) provide evidence of a significant inverse relationship between the financial health of UK firms and the firm-specific implicit interest rate, which they define as the ratio of interest payments to the moving average of three years of total debt centred at the current year.

\footnotetext{
${ }^{4}$ Our results were robust to using a pooled and random-effects probit model, as well as a linear probability model. The results, which are available upon request, remained largely unchanged.
} 
Finally, recent evidence by Spaliara (2009) shows that the capital-labor ratio of financially constrained UK firms is more sensitive to the interest burden compared to that of their unconstrained counterparts.

Moving this literature forward, we employ the interest burden to capture, for the first time, the effects of a change in debt-servicing costs on firm survival. In the spirit of Nickell and Nicolitsas (1999), Benito (2005), and Benito and Young (2007), we measure the interest burden using the ratio of interest payments to cash flow. Increases in interest payments should negatively affect firms' financial position, therefore raising the interest burden. In turn, we expect higher levels of the interest burden to be associated with lower chances of firm survival.

In addition to the interest burden, the vector $X$ comprises three additional financial variables aimed at capturing the effects of financial health on the likelihood of survival. These include solvency (SOLV), measured as the ratio of shareholders' funds to total assets; the leverage ratio ( $L E V$ ), defined as the ratio of the firm's current liabilities to total assets; and the profitability ratio (PROF), defined as the ratio of earnings before interest and taxes to total assets ${ }^{5}$. The vecor $X$ also includes the following additional firm-specific characteristics, which, according to the literature, affect firm survival: size (SIZE), measured as the logarithm of total real assets; age (AGE), defined as the difference between the present year and the firm's date of incorporation; and the dummy variable GROUP, which takes value one if the firm is part of a group, and zero otherwise. We also control for macroeconomic conditions by including the real effective exchange rate (EXCHANGE), calculated as the geometric weighted average of bilateral effective

\footnotetext{
${ }^{5}$ Contemporaneous values of the interest burden and our financial variables are included in our firm survival equation. Our results were robust to lagging these variables once to mitigate potential endogeneity concerns.
} 
exchange rates adjusted by relative consumer prices. Lastly, $X$ contains a set of industry and time dummies that control respectively for industry and business cycle effects ${ }^{6}$.

\section{Accounting for differences between crisis and non-crisis periods}

In order to investigate the extent to which, controlling for other factors, firm survival differs in crisis years compared to more tranquil periods, we include in vector $X$ of Equation (1) a financial crisis dummy (CRISIS), which takes value one over the period 2007-09, and zero otherwise ${ }^{7}$. The coefficient associated with the CRISIS dummy is aimed at capturing the marginal effect of the crisis on firm survival, holding everything else equal.

We next investigate whether in addition to having a direct effect on firms' chances of survival, the financial crisis may also have an indirect impact by magnifying the effect of firms' interest burden on survival. To this end, we examine whether the sensitivity of firms' survival prospects to changes in the interest burden differs between crisis and tranquil periods. Specifically, we include in the vector $X$ of Equation (1) an interaction between the interest burden (IB) and the CRISIS dummy, and an interaction between the interest burden (IB) and the (1-CRISIS) dummy. Comparing the coefficients on these two interaction terms enables us to assess the extent to which changes in the interest burden have a different effect on firms' survival during tranquil and crisis periods. This test is motivated by the financial accelerator-related hypothesis according to which a deterioration of economic conditions negatively affects the health of firms' balance sheets. In these circumstances, firms facing increased debt-servicing costs might face a higher

\footnotetext{
${ }^{6}$ Section 1 in the online Appendix provides a thorough discussion of the effects that each of these variables is likely to have on firms' survival chances, in the light of the literature.

${ }^{7}$ Our results were robust to defining the dummy CRISIS equal to one in 2008-09, and 0 otherwise.
} 
probability of failure during the crisis than outside. We therefore expect the effects of changes in the interest burden on firms' chances of failure to be stronger during the crisis.

\section{Accounting for firm heterogeneity}

We next explore the extent to which an increase in the interest burden may have a different impact on the survival chances of firms characterized by different degrees of financing constraints, taking into account the effect of the financial crisis. This test is motivated by Nickell and Nicolitsas (1999), who analyze the effects of changes in firms' borrowing ratio on their employment decisions, differentiating firms on the basis of the degree of financial pressure they face ${ }^{8}$.

Following the literature (Kashyap et al., 1993; Huang, 2003; Guariglia and Mateut, 2006), we use bank dependency as our first indicator of the degree of financing constraints faced by firms. This can be justified in the light of the fact that it is generally risky and low credit firms, which rely on bank finance (Huang, 2003). As in Guariglia and Mateut (2006), we define bank-dependent firms in two ways: the first is based on their ratio of short-term debt to the sum of short-term debt and trade credit (mix1), and the second on their ratio of short-term debt to total current liabilities (mix2). Specifically, we create a dummy variable BankDep1 (BankDep2) which is equal to one for firm $i$ in year $t$ if firm $i$ 's mix1 (mix2) falls in the top $50 \%$ of the distribution of the mix1s (mix2s) of all firms operating in the same industry as firm $i$ in year $t$, and zero otherwise. As short-term debt is

\footnotetext{
${ }^{8}$ Nickell and Nicolitsas (1999) identify stronger effects of shifts in the borrowing ratio for companies which are under greater long-term financial pressure. They proxy long-term financial pressure using firm size, the dividend payout ratio, and the debt to capital ratio.
} 
predominately made up of bank finance, the BankDep1 and BankDep2 dummies are good proxies of bank dependency.

We next partition our sample into young and old firms using the age of incorporation as a sorting device. We define a firm as young (old) in a given year if its age falls in the bottom (top) $50 \%$ of the age distribution of all firms operating in the same industry as this firm in that year, and 0 otherwise. Spaliara (2009) and Hadlock and Pierce (2010) note that young firms are less known and have not established a track record in the market. Consequently, they are more likely to be associated with a higher degree of informational asymmetry, and are less likely to have access to capital markets.

Finally, we differentiate firms between exporters and non-exporters, whereby the latter are firms that never exported throughout the sample period. It has been found that exporters are generally financially healthier than non-exporters (Greenaway et al., 2007; Guariglia and Mateut, 2010). This could be explained by three important considerations. First, exporters have access to both domestic and international financial markets, which enables them to diversify their sources of financing and the associated risks. Second, they are less tied to the domestic cycle, and less subject to those financial constraints induced by tight monetary policy and recessions at home. ${ }^{9}$ They therefore benefit from a more stable cash flow, which, providing greater assurance to lenders that the firm will be able to service its obligation, relaxes their liquidity constraints (Guariglia and Mateut, 2010). Finally, given the presence of sunk costs that need to be met when entering foreign markets for the first time (Roberts and Tybout, 1997), being an exporter also provides a signal that the firm is sufficiently productive to generate enough profits in foreign markets to recover

\footnotetext{
${ }^{9}$ This argument relies on the assumption that business cycles are not perfectly coordinated across countries.
} 
the sunk costs. This increases the likelihood that the firm will be able to service its external debt, and further relaxes the liquidity constraints that it faces.

To take firm heterogeneity into account, we estimate the following specification:

$$
\begin{aligned}
& h(j, X)=1-\exp \left[-\exp \left(\beta_{0}+\beta_{1} I B * C O N S * C R I S I S+\beta_{2} I B * C O N S *(1-\text { CRISIS })\right.\right. \\
& +\beta_{3} I B *(1-C O N S) * C R I S I S+\beta_{4} I B *(1-C O N S) *(1-\text { CRISIS })+\beta_{5} \text { CRISIS }+\beta_{6} \text { LEVERAGE }+ \\
& \left.\left.\beta_{7} \text { SOLVENCY }+\beta_{8} \text { PROFIT }+\beta_{9} \text { SIZE }+\beta_{10} A G E+\beta_{11} \text { GROUP }+\beta_{12} \text { EXCHANGE }+\gamma_{j}\right)\right]
\end{aligned}
$$

where CONS is a dummy variable equal to 1 if the firm is (in turn) bank-dependent, young, or a non-exporter, and 0 otherwise. We expect the effect of a rise in the cost of finance on the survival of both constrained and unconstrained firms to be stronger during the financial crisis, as financial intermediaries became reluctant to lend money to these firms (Parker and Eaglesham, 2008; Bank of England, 2009; Fraser, 2009) and/or charged them higher interest rates (Bell and Young, 2010; Santos, 2013), further jeopardizing their survival chances (i.e. we expect to observe that $\beta_{1}>\beta_{2}$ and that $\beta_{3}>\beta_{4}$ ). Moreover, we expect an increase in $I B$ to have a more severe impact on the survival of more bank-dependent firms compared to their less bank-dependent counterparts. The same is true for young versus old firms, as well as non-exporters versus exporters (i.e. we expect to observe that $\beta_{1}>\beta_{3}$ and that $\left.\beta_{2}>\beta_{4}\right)$.

\section{Data and summary statistics}

\section{Data}

Our data set is drawn from the annual accounting reports taken from the Financial Analysis Made Easy (FAME) database, published by Bureau Van Dijk Electronic Publishing 
$(B v D E P)$. The full version of the FAME database provides information on 2.8 million companies (1.9 million of which are in a detailed format) over the period $2000-2009^{10}$.

To construct our data set, we use three different versions of FAME. In particular, we employ FAME October 2010, FAME October 2008, and FAME February 2005. In line with Helmers et al. (2011) and Javorcik and Li (2013), we take this approach to address potential attrition bias since FAME keeps only firms that have not been inactive for more than four years. Therefore, if only the 2010 version of FAME were used, we would miss firms that exited by 2006 or possibly 2005. Thus, our dataset is able to track firm exits up to the earlier part of the sample period.

To accurately construct our dependent variable we also take into account that some firms may exit due to mergers and acquisitions. Following Helmers and Rogers (2010) and Görg and Spaliara (2014), we use Bureau Van Dijk’s ZEPHYR database, which contains information on mergers and acquisitions, to identify and drop those firms that are mistakenly coded as "failed" in our data. This ensures that our indicator variable has been accurately constructed to capture firms that failed and did not exit due to mergers and acquisitions.

Following normal selection criteria used in the literature, we drop observations with negative sales, as well as observations with negative total assets. Firms that do not have complete records on our main regression variables are also dropped. To control for the potential influence of outliers, we exclude observations in the $1 \%$ tails for each of our regression variables. Our final panel, which is unbalanced, includes 20,238 firms and

\footnotetext{
${ }^{10}$ It is noteworthy that three types of access to the FAME database are available. Type $\mathrm{C}$ gives access to all firms in the database, while types B and A exclude in turn subsets of the smallest companies. Our dataset is based on type A access. In addition, a maximum of ten years of complete data history can be downloaded at once. We have only selected firms that have unconsolidated accounts: this ensures that the majority of the firms in our dataset are relatively small. Moreover, it avoids the double counting of firms belonging to groups, which would be included in the dataset if firms with consolidated accounts were also part of it.
} 
136,982 observations ${ }^{11}$. This represents approximately $20 \%$ of the UK manufacturing sector excluding sole proprietorships and partnerships with self-employed ownermanager(s $)^{12}$. The vast majority of firms included in this dataset are not traded on the stock market. This is an appealing characteristic since unquoted firms are more likely to be associated with a higher degree of information asymmetry and therefore more likely to face an increased probability of failure, especially during extreme economic conditions (Hughes, 1994) ${ }^{13}$.

\section{Summary statistics}

Tables 1 presents descriptive statistics of all variables used in our empirical models for the entire sample. We distinguish between failed and surviving firms (columns 2 and 3); and crisis and tranquil periods (columns 5 and 6). In columns 4 and 7 we report $p$-values of a test for the equality of means. We can see that the average failure rate in our sample is 14.3\%, which is much higher compared with previous UK studies (Bunn and Redwood, 2003 and Bridges and Guariglia, 2008). The difference between our figures and theirs is probably due to the fact that their sample covers a much earlier time period (up to 2003). It is therefore possible that failure rates have increased over the most recent years. Our figures are consistent with the Structural Business Statistics reported by Eurostat, according to which the average failure rate between 2000 and 2009 in the manufacturing sector is approximately 10\%. When comparing failing and surviving firms (columns 2 and 3), we note that the former are charged a significantly higher interest for servicing shortterm debt. Moreover, surviving firms are less indebted, more profitable, and less solvent

\footnotetext{
${ }^{11}$ See Section 2 of the online Appendix for information about the structure of our panel (Table A1) and for precise definitions of all the variables used. Also see Sections 3 and 4 of the online Appendix for a discussion on the representativeness of our sample and on whether our sample selection criteria generate bias.

${ }^{12}$ The data are taken from the Department of Business and Innovations Skills, Small and Medium-sized Enterprise Statistics for the UK and Regions (http://stats.bis.gov.uk/ed/sme).

${ }^{13}$ Also see Bunn and Redwood (2003), Bridges and Guariglia (2008), Helmers and Rogers (2010, 2011), and Görg and Spaliara (2014), who used the FAME dataset to study business failures in the UK.
} 
than their failed counterparts. These findings are in line with Bunn and Redwood (2003), Bridges and Guariglia, (2008), and Görg and Spaliara (2014). Furthermore, survivors are larger, older, and more likely to be part of a group. These differences between sub-samples are statistically significant in all cases (column 4).

When comparing the 2007-09 financial crisis period with the earlier years of our sample (columns 5 and 6), we observe that the average failure rate is higher during the crisis. Yet, although the difference in failure rates during and outside the crisis is statistically significant at the $1 \%$ level (column 7 ), it is actually not very large. Three factors can explain the relatively low number of insolvencies over the crisis period. First, the relatively healthy position of the corporate sector prior to the crisis may have played a role. Second, the forbearance by banks on existing loans, together with the low level of the Bank Rate may have enabled businesses to continue trading despite the lower demand and related losses. Third, the relatively few company liquidations may be explained by effects of monetary and fiscal policies implemented during the financial crisis period (see Benito el al., 2010, and Bank of England, 2012). It should be noted, however, that the overall low number of UK insolvencies during the 2007-2009 period hides the fact that survival was a major problem for UK SMEs.

Moving to the interest burden, we note that this variable takes the value of $37.5 \%$ during the crisis, while it equals $35.8 \%$ during tranquil periods. Once again, this difference is statistically significant. It is also noteworthy that the average interest burden in our sample is higher than that reported by Benito (2005) and Benito and Young (2007). This can be explained considering that, contrary to ours, their study focuses on UK listed companies, which are likely to be less indebted than their unlisted counterparts. This higher interest burden during the crisis is driven by an increase in interest payments, rather than by a decline in cash flow. Specifically, according to our data, average interest 
payments increased by $72 \%$ during the crisis period. The difference in the mean interest payment figures across the crisis and preceding periods is statistically significant at the $1 \%$ level. On the other hand, average cash flow actually increased by 5\% in the crisis period, and the difference in mean cash flow during and before the crisis is only marginally significant ${ }^{14}$. This confirms that during the financial crisis, firms faced an increase in the debt-servicing cost. Specifically, the higher interest burden observed in the period 20072009 is mainly due to the increase in the spread over the reference rate at which loans were offered. As explained in Bank of England (2009), “increases in spreads are likely to reflect in part a re-pricing due to increased perceptions of credit risk, following a prolonged period earlier in the decade where corporate credit risks were underpriced” (pp. 6-7). ${ }^{15}$

In summary, these preliminary statistics suggest that firms' failure rates may be related to the interest burden, financial health, and the recent financial crisis. In the sections that follow, we provide a formal econometric analysis on the links between these variables ${ }^{16}$

\section{Empirical results}

\section{Firm survival, financial crisis, and the role of interest burden}

In this section we shed light on the role played by changes in the interest burden on firms’ survival before and during the recent financial crisis. A few papers have considered the impact of financial pressure on firms’ real decisions (Nickell and Nicolitsas, 1999; Benito, 2005; and Benito and Young, 2007). In particular, they have documented significant effects of debt-servicing costs on investment expenditures, dividend payments, inventory investment, and employment. Given that debt-servicing costs increased during the recent

\footnotetext{
${ }^{14}$ These numbers are not reported in the Table for brevity.

${ }^{15}$ A similar point with reference to UK loan spreads is also made by Bell and Young (2010). Also see Fraser (2009) for an illustration of the extent to which the cost of loans to SMEs increased during the recent financial crisis.

${ }^{16}$ Additional summary statistics are reported in Section 5 of the online Appendix.
} 
crisis as evidenced by Bell and Young (2010), we take one step further and evaluate the effects of changes in the interest burden on firm survival, and assess whether these effects were magnified during the financial crisis. Table 2 presents the estimates of our survival equations. In column 1, the interest burden is included in the estimating equation along with a number of firm-specific and other control variables. The coefficient associated with the interest burden enables us to assess the consequences of a ceteris paribus increase in interest burden on the probability of firm exit. Column 2 includes both the interest burden and the crisis dummy, and column 3 includes the crisis dummy, as well as the indirect effect of the crisis through interactions with the interest burden.

Starting with column 1, we observe that the firm-specific interest burden exerts a positive and highly significant effect on firm failure. Considering that the predicted exit probability evaluated at the mean of the independent variables is $3.5 \%$, the coefficient on $I B$ suggests that a one percent increase in the interest burden is associated with a rise in the predicted exit probability of around $[\exp (0.614)-1] * 3.5=2.96$ percentage points. Consistent with our expectations, increases in the debt-servicing costs affect firms' survival prospects negatively. This is in line with other studies which find a negative effect of debt-servicing costs on investment expenditures, dividend payments, inventory investment, and employment (Nickell and Nicolitsas, 1999; Benito, 2005, and Benito and Young, 2007) $)^{17,18}$

Column 2 includes the crisis dummy and is aimed at evaluating the marginal effect of the crisis on firm survival, holding everything else equal. The crisis dummy attracts a

\footnotetext{
${ }^{17}$ Even though our equation controls for a range of variables that typically affect corporate death rates, one could argue that a higher interest burden and firm exit may be driven by the same unobservable variables and therefore may seem to occur at the same time, without a causal link running from the former to the latter. In order to convince readers that this is not the case, we show that our results are robust to lagging the interest burden, using Instrumental Variable (IV) pooled linear and probit models, a simple fixed-effects model, a conditional Logit fixed-effects model, an IV fixed-effects model, and a two stage least squares model estimated in first-differences. The results of these approaches are reported and discussed in Section 7 of the online Appendix.

${ }^{18}$ Other coefficients in the Table are discussed in Section 6 of the online Appendix.
} 
positive coefficient, which can be explained considering that during downturns, economic activity faces a general slowdown which is likely to affect firm survival. The coefficients on the interest burden, control, and financial variables are similar to those reported in column 1.

When we include the interactions between the interest burden and the crisis/noncrisis dummies in column 3, we find a positive and highly significant effect of the firmspecific interest rate on the likelihood of exit both in and out of the crisis. However, the results suggest that firms respond differently to the financial pressure of servicing debt throughout the cycle: increases in interest payments have a greater impact on the hazard of failure during the crisis than outside. The difference in this effect across the two time periods is economically important: a one percent increase in the interest burden raises in fact the predicted exit probability by $9.68 \%$ over the period $2007-2009$, but only by $2.18 \%$ during tranquil periods. The $p$-value for the equality of the coefficients indicates a statistically significant difference between the two coefficients. It is also interesting to notice that once the interaction terms are added to the equation, the CRISIS dummy loses its significance. This suggests that the crisis affected firm survival mainly indirectly, by magnifying the effect of changes in the interest burden. This can be explained in the light of the financial accelerator hypothesis, according to which the effects of changes in firms' balance sheet positions on their activities, and hence their survival, are magnified during recessionary periods (Bernanke et al., 1996; Perez-Quiros and Timmermann, 2000). Another explanation for our findings could be that, during the crisis, banks became less tolerant of companies facing a high interest burden, which may reflect a change in their risk appetite. In other words, because they were concerned about their own balance sheets due to the increased risk of non-performing loans and write-offs, banks monitored their borrowers more closely and became generally more cautious in their lending practices 
(Kara et al., 2011). In line with this argument, Ivashina and Scharfstein (2010), Bell and Young (2010), and Almeida et al. (2013) note a significant reduction in the supply of bank credit in both the US and the UK during the crisis.

In a nutshell, our results so far suggest that higher levels of the interest burden are likely to have increased firms' chances of failure during the recent financial crisis. To provide further support to this conclusion, we have partitioned our sample into firm-years that experienced a rise in their interest burden, and firm-years whose interest burden either stayed constant or declined. Focusing on the entire sample, the former experienced an average failure rate of $16.11 \%$, while the average failure rate of the latter was only $5.27 \%$. The difference between the two rates is statistically significant at the $1 \%$ level. This confirms that an increasing interest burden is generally associated with a higher failure rate. In addition, as shown in Figure A12 in Section 8 of the online Appendix, only those firm-years that experienced a rise in the interest burden show a significant rise in their failure rates over the crisis period. Other observations actually show a declining failure rate $^{19}$. This confirms that rising interest payments are likely to have been one of the driving factors explaining the high exit of firms during the recent financial crisis.

\section{Differentiating firms according to their degree of bank dependency, age, and}

\section{exporting activity}

In Table 3, we investigate whether changes in interest payment obligations have a differential impact on the hazard of failure of firms more and less likely to face financing constraints, in and out of the crisis. We expect more bank-dependent firms to face a higher sensitivity of failure to changes in the interest burden. The same argument holds for young

\footnotetext{
${ }^{19}$ In unreported statistics, we show that it is mainly bank-dependent firms and non-exporters who suffered a significant increase in the interest burden over the crisis period.
} 
and non-exporting firms, which are typically more financially constrained than their older and exporting counterparts.

We label bank-dependent (columns 1 and 2), young (column 3), and non-exporting firms (column 4) as “constrained". The interest burden is interacted with both the constrained/unconstrained dummies and the crisis/non-crisis dummies to gauge the extent to which the effects of debt-servicing cost on the likelihood of failure differ for more and less-financially constrained firms throughout the business cycle. The emphasis is put on the differential behavior of firms more likely to face financial constraints during and outside the crisis, but we also check for differences in the behavior of unconstrained firms over the two periods. To ensure that our results are robust, we carry out our estimations using two different classification criteria for bank dependency, based on firms' short-term debt to the sum of short-term debt and trade credit (BankDep1, column 1) and short-term debt to total current liabilities (BankDep2, column 2).

Focusing on rows 1 and 2 of Table 3, we observe that for bank-dependent, young, and non-exporting firms, the interest burden exhibits a much larger coefficient during the crisis than outside. A test for the equality of the coefficients is reported at the foot of the Table. It shows that the differences in the coefficients on the interest burden for constrained firms during and outside the crisis are statistically significant.

We next compare rows 3 and 4 and observe that the estimated coefficients on the interest burden are positive and significant for unconstrained firms both in and out of the crisis, and, once again, generally higher in the crisis. The $p$-values for the test of the differences in these coefficients show that they are once again statistically significant.

Next, we compare the coefficients on the interest burden at constrained and unconstrained firms during the crisis (rows 1 and 3). We observe that the sensitivity of the firms' chances of survival to changes in the interest burden is always higher for the former. 
The $p$-values reported at the foot of the Table reveal that in two out of four cases, during the crisis, the coefficients on the interest burden for constrained firms are significantly different from those of unconstrained firms ${ }^{20}$.

Access to capital markets is likely to be prohibitively expensive for financially constrained firms, which are more likely to depend on banks for external finance. During the financial crisis, the strong reliance of these firms on bank debt had disastrous effects on their viability given the shortage of bank credit available in the market. It is in fact documented that during the crisis, most banks tightened lending standards. As a consequence of this, those bank-dependent financially constrained firms had to scale back their investment projects and restrain their activities. Consequently, it is not surprising that following a rise in their debt obligations, more-bank-dependent, young and non-exporting firms were more likely to fail during the crisis.

The last pair of interactions to be compared are those in rows 2 and 4 . Results for both constrained and unconstrained firms during tranquil periods are mixed. When bank dependency is used as a measure of constraints, the effect of changes in the interest burden on firm chances of survival is higher for more bank-dependent firms. Yet, when age and exporting are employed as sorting devices, the effect is higher for older and equal for exporting firms. In these cases, however, the differences in the relevant coefficients are not statistically significant at conventional levels.

In summary, the greater sensitivities of firm survival to changes in the interest burden documented for more-bank-dependent, young, and non-exporting firms during the

\footnotetext{
${ }^{20}$ This happens when we use the bank dependency criteria to differentiate firms into more and less likely to face financing constraints, and may be indicative of the importance of being bank-dependent during the crisis.
} 
crisis than outside confirms that rising interest payments are likely to have been one of the driving factors explaining the high exit of financially constrained firms during the crisis $^{21}$.

\section{Conclusions}

The literature on business failures has mainly considered the effects of direct measures of firms' balance sheet health on firms' survival chances. In this paper we take a different angle by examining, for the first time, the role of firm-specific interest payments, measured by the interest burden, in determining firm survival. Our results, based on firm-level data for the UK over the period 2000 to 2009, suggest that there is a strong link between debtservicing costs and firm survival. This link is particularly strong during the 2007-09 financial crisis, during which firms became more likely to fail as a consequence of an increase in their interest burden. When we differentiate firms into more and less likely to face financing constraints, we find that survival chances at bank-dependent, younger, and non-exporting firms are the most severely affected by changes in interest payments, especially during the crisis. Our results are robust to using different estimation methods and different interest burden measures.

The increased cost of servicing debt which triggered the rise in the interest burden over the period 2007 to 2009 may have been a driving factor for many of the corporate failures which accompanied the crisis. This can be explained considering that banks became less tolerant of companies facing a high interest burden during the crisis, which may reflect a change in their risk appetite. In other words, because during economic slowdowns, banks face a higher risk of non-performing loans and write-offs, they tend to

\footnotetext{
${ }^{21}$ As our sample separation criteria (with the exception of age) may be endogenous, we tested whether our results were robust to using pre-sample bank dependency and export status to partition our sample. These results, which are not reported for brevity but available upon request, were very similar to those reported in Table 3. Our results were also robust to controlling for the possible endogeneity of our financial variables by using instrumental variables (IV) probit models, and to using an alternative measure of the interest burden, namely the ratio of interest payments to total debt. These robustness tests are discussed respectively in Sections 9 and 10 of the online Appendix.
} 
monitor their borrowers more closely and are generally more cautious in their lending practices (Kara et al., 2011). The reduction in the supply of bank loans directed towards firms with a high interest burden is likely to have prevented these firms from investing, and ultimately to have hastened their exit from the market.

The resulting policy implications are important, in particular, but not only, in the current economic climate. We suggest that policymakers should prevent financing costs from rising during economic downturns. This implication is reflected in the extraordinary measures the Bank of England has taken during the financial crisis period. Specifically, the fact that the Bank of England's own policy rate was reduced to a historic low of $0.5 \%$ is likely to have significantly contributed to the lower corporate failure rates. In addition, several other policies aimed at making low cost credit readily available to financially constrained firms, such as the $£ 190$ billion Project Merlin, the National Loan Guarantee Scheme, the Funding for Lending Scheme (FLS), and the Discount Window Facility (DWF) are also likely to have helped stabilise the UK market and improve firms' performance and survival prospects ${ }^{22}$.

\section{References}

Almeida, H., Campello, M., Cunha, I., and Weisbach, M. (2013). 'Corporate liquidity management: A conceptual framework and survey', National Bureau of Economic Research Working Paper No. 19502.

Bandick, R. and H. Görg (2010). 'Foreign acquisition, plant survival, and employment growth', Canadian Journal of Economics, Vol. 43, pp. 547-573.

Bank of England (2009). Trends in Lending, May 2009.

Bank of England (2012). Inflation Report, November 2012.

${ }^{22}$ These policies are described in Section 11 of the online Appendix. 
Bell, V. and G. Young (2010). 'Understanding the weakness of bank lending', Quarterly Bulletin, Q4, Bank of England.

Benito, A. (2005). 'Financial pressure, monetary policy effects and inventories: firm-level evidence from a market-based and a bank-based financial system’, Economica, Vol. 72, pp. 201-224.

Benito, A. Nelss, K., Price, S. and K. Rachel (2010). 'The impact of the financial crisis on supply’, Quarterly Bulletin, Q2, Bank of England.

Benito, A. and J. Whitley (2003). 'Implicit interest rates and corporate balance sheets: An analysis using aggregate and disaggregated UK data’, Working Paper No. 193, Bank of England.

Benito, A. and G. Young (2007). 'Financial pressure and balance sheet adjustment by firms', Oxford Bulletin of Economics and Statistics, Vol. 69, pp. 581-602.

Bernanke, B. and M. Gertler. (1995). 'Inside the black box: The credit channel of monetary policy transmission', Journal of Economic Perspectives, Vol. 9, pp. 27-48.

Bernanke, B., Gertler, M., and Gilchrist, S. (1996). 'The financial accelerator and the flight to quality', Review of Economics and Statistics, Vol. 78, pp. 1-15.

Bridges, S. and A. Guariglia (2008). 'Financial constraints, global engagement, and firm survival in the U.K.: Evidence from micro data', Scottish Journal of Political Economy, Vol. 55, pp. 444-464.

Bunn, P. and V. Redwood (2003). 'Company accounts based modelling of business failures and the implications for financial stability', Working Paper No. 210, Bank of England.

Fraser, S. (2009). 'Small firms in the credit crisis: evidence from the UK survey of SME finances.’ Warwick Business School (ESRC grant no. RES-177-25-0007).

Goodhart, C. (2008). 'The background to the 2007 financial crisis', International Economics and Economic Policy, Vol. 4, pp. 331-346. 
Görg, H. and M.E. Spaliara (2014). 'Financial health, exports, and firm survival: Evidence from UK and French firms’, Economica, Vol. 81, pp. 419-444.

Greenaway, D., Guariglia, A., and Kneller, R. (2007). 'Financial factors and exporting decisions', Journal of International Economics, Vol. 73, pp. 377-95.

Guariglia, A. and Mateut, S. (2006). 'Credit channel, trade credit channel, and inventory investment: Evidence from a panel of UK firms', Journal of Banking and Finance, Vol. 30, pp. 2835-56.

Guariglia, A. and Mateut, S. (2010). 'Inventory investment, global engagement, and financial constraints in the UK: evidence from micro data', Journal of Macroeconomics, Vol. 32, pp. 239-50.

Hadlock, C. and Pierce, J. (2010). 'New evidence on measuring financial constraints; Moving beyond the KZ index', Review of Financial Studies, Vol. 23, pp. 1909-1940.

Helmers, C. and M. Rogers (2010). 'Innovation and the survival of new firms in the UK', Review of Industrial Organization, Vol. 36, pp. 227-248.

Helmers, C. and M. Rogers (2011). 'Does patenting help high-tech start-ups?' Research Policy, Vol. 40, pp. 1016-1027.

Helmers, C., Rogers, M., and P. Schautschick (2011). 'Intellectual property at the firm-level in the UK: The Oxford firm-level intellectual property database’, Working Paper No. 546, University of Oxford

Huang, Z. (2003). 'Evidence of a bank lending channel in the UK', Journal of Banking and Finance, Vol. 27, pp. 491-510.

Hughes, A. (1994). 'Finance for SMEs: a UK perspective’, Small Business Economics, Vol. 9, pp. 151-168.

Ivashina, V. and D. Scharfstein (2010). 'Bank lending during the financial crisis of 2008', Journal of Financial Economics, Vol. 97, pp. 319-338. 
Javorcik, B. and Y. Li (2013). 'Do the biggest aisles serve a bright future? Global retail chains and their implications for Romania', Journal of International Economics, Vol. 90, pp. 348-63.

Kahle, K. and R. Stulz (2013). 'Access to capital, investment, and the financial crisis', Journal of Financial Economics, Vol. 110, pp. 280-299.

Kara, A., Marques, D., and S. Ongena. (2011). 'Securitization and lending standards: Evidence from the wholesale market’, European Central Bank, Working Paper No. 1362.

Kashyap, A., Stein, J., and W. Wilcox. (1993). 'Monetary policy and credit conditions: evidence from the composition of external finance', American Economic Review, Vol. 83, pp. 78-98.

Kirkup, J. and R. Tyler (2008). 'Interest rate cut: Small businesses could save £750 million on loans', The Telegraph, 06 November 2008.

Kuchler, H. (2012). 'Poor access to cash limits SME growth’, Financial Times, March 11.

Mojon, B. Smets, F. and P. Vermeulen (2002). 'Investment and monetary policy in the Euro area’, Journal of Banking and Finance, Vol. 26, pp. 2111-2129.

Nickell, S. and D. Nicolitsas (1999). 'How does financial pressure affect firms?' European Economic Review, Vol. 43, pp. 1435-1456.

Parker, G. and J. Eaglesham (2008). 'Darling lifeline for small companies', Financial Times (19 November).

Perez-Quiros, G and Timmermann, A. (2000). 'Firm size and cyclical variations in stock return', Journal of Finance, Vol. LV, pp. 1229-1262.

Roberts, M. and Tybout, J. (1997). 'The decision to export in Colombia: an empirical model of entry with sunk costs’, American Economic Review, Vol. 87, pp. 545-64.

Rose, A. and M. Spiegel (2011). 'Cross-country causes and consequences of the crisis: An update’, European Economic Review, Vol. 55, pp. 309-24. 
Santos, J. (2011). 'Bank corporate loan pricing following the subprime crisis', Review of Financial Studies, Vol. 24, pp. 1916-43.

Santos, J. and A. Winton (2008). 'Bank loans, bonds, and informational monopolies across the business cycle', Journal of Finance, Vol. 63, pp. 1315-1359.

Spaliara, M. (2009). 'Do financial factors affect the capital-labour ratio? Evidence from UK firm-level data’, Journal of Banking and Finance, Vol. 33, pp. 1932-1947.

Tsoukas, S. (2011). 'Firm survival and financial development: Evidence from emerging Asian economies', Journal of Banking and Finance, Vol. 35, pp. 1736-1752.

Vermeulen, P. (2002). 'Business fixed investment: Evidence of a financial accelerator in Europe', Oxford Bulletin of Economics and Statistics, Vol. 64, pp. 217- 235. 